\title{
Distribution patterns of fishes in a freshwater deprived Eastern Cape estuary, with particular emphasis on the geographical headwater region
}

\author{
AK Whitfield* and AW Paterson \\ South African Institute for Aquatic Biodiversity, Private Bag 1015, Grahamstown 6140, South Africa
}

\begin{abstract}
Small seine net fish assemblages in the headwater region of the Kariega Estuary are described and compared to the catch composition in other parts of the system. The geographical headwaters of the freshwater 'deprived' Kariega Estuary were utilised by a range of fish species but, in contrast to the nearby freshwater 'rich' Great Fish Estuary, few important angling species (e.g. spotted grunter Pomadasys commersonnii and dusky kob Argyrosomus japonicus) were recorded. The reduced riverine flow into the Kariega Estuary resulted in an extremely restricted river-estuary interface (REI) zone being made available to resident and migrant fish species. Despite the low freshwater input recorded, the catadromous freshwater mullet Myxus capensis was abundant within the REI zone and headwater reach, probably due to reduced access to riverine habitat above the estuary. Although salinity has been shown to be an important structuring force influencing ichthyofaunal assemblages in many South African estuaries, it is not the primary factor governing the distribution of fish in a freshwater-deprived, marine-dominated system such as the Kariega.
\end{abstract}

\section{Introduction}

Biological research in South African estuaries has been concentrated on the lower and middle reaches of systems, with little information being available from the geographic headwaters or upper reaches. Research on fish communities in South African estuaries has followed a similar pattern, with few studies examining the entire length of an estuary, the notable exception being a recent study on the Great Fish River Estuary (Ter Morshuizen et al., 1996; 1997). This lack of information on the longitudinal distribution of fish within estuaries is compounded by the paucity of studies that rigorously examine the factors, both abiotic and biotic, which structure these communities. Advances in multivariate statistics have enhanced numerical ecology, but the majority of studies examining spatial and temporal variation in fish communities have been analysed using conventional univariate statistics (Ter Morshuizen and Whitfield, 1994). Research into the forces that structure fish communities has also focused on the relationship between fishes and a single abiotic variable (e.g. Cyrus and Blaber, 1987a; 1987b), with only a few using multivariate techniques to link fish species to a range of environmental parameters (Morin et al., 1992; Thiel et al., 1995; Marshall and Elliott, 1998). This study aims to use multivariate techniques to examine the longitudinal variation in Kariega Estuary fish assemblages and the factors that influence them.

\section{Study area}

The permanently open Kariega Estuary is situated on the east coast of South Africa (33 $41^{\circ} \mathrm{S}, 26^{\circ} 42^{\prime} \mathrm{E}$ ) and is approximately $18 \mathrm{~km}$ long (Fig. 1). The channel in the upper reaches is narrow (40 to $60 \mathrm{~m}$ ) while in the lower reaches the estuary widens $(100 \mathrm{~m})$ and is bordered by sand flats and salt marshes (Grange, 1992). The

* To whom all correspondence should be addressed. 푱046 6035829; fax 046 6222403; e-mail: A.Whitfield@ru.ac.za Received 29 January 2001; accepted in revised form 7 November 2002.

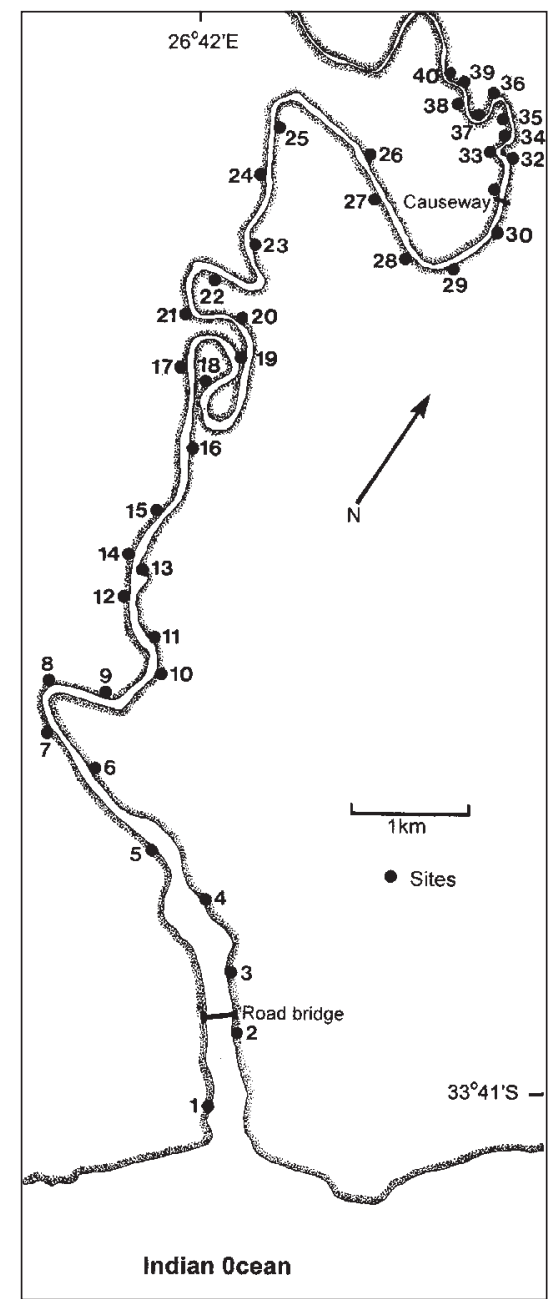

Figure 1

Map of the Kariega Estuary indicating sampling sites used in this study 
estuary has an average midstream depth of between 2.5 and $3.5 \mathrm{~m}$ and was formed by the drowning of a river valley following a rise in sea level (Reddering and Rust, 1990).

The Kariega Estuary is currently a marine dominated system with very little riverine influence. The system is often hypersaline in the upper reaches and, apart from episodic freshwater inputs, river inflow is negligible for extended periods (Hodgson, 1987; Allanson and Read, 1995; Grange et al., 2000). This low freshwater input into the system is due to the Eastern Cape being relatively arid, which is exacerbated by a very poor rainfall to runoff conversion. In addition, the catchment of the Kariega Estuary is small $\left(686 \mathrm{~km}^{2}\right)$ and highly regulated by three dams and numerous farm weirs. The only river water entering the estuary during the current study (January - December 1999) was limited to a small trickle at Site 40 (Fig. 1). For the purposes of this study the RiverEstuary Interface (REI) zone definition of Bate et al. (2002) is used, i.e. that sector of the estuary where integrated vertical salinity values are generally less than $10 \%$.

With a strong marine influence and negligible riverine input, the salinity is usually uniformly marine (35\%) along most of the estuary length. The system has a low turbidity $(<10$ NTU) and is well mixed with almost no salinity or thermal stratification of the water column at any stage of the tidal cycle (Grange and Allanson, 1995). As a consequence of the low riverine input and the resulting poor nutrient status of the system (Allanson and Read, 1995), the phytoplankton stocks are low and the water column can be regarded as being oligotrophic. Zostera capensis occurs mostly as a littoral band just above and below the low-water spring tide level and the mean width of the beds varies from $5.2 \mathrm{~m}$ in the lower reaches to $3.3 \mathrm{~m}$ in the upper reaches (Ter Morshuizen and Whitfield, 1994). A stone causeway, which cannot be traversed by fish at spring low tide, is located between Sites 30 and 31 (Fig. 1). However, during other stages of the tidal cycle, the two concrete culverts at the base of the causeway are fully inundated and allow the passage of fish up and down the estuary.

\section{Materials and methods}

This study was divided into two main sections, namely a headwater fish component and an overall fish distribution component. The headwater study primarily examined the fish community found in the headwaters of the Kariega Estuary and focused on species composition, diversity, life-history stages and seasonality. The fish distribution study examined fish assemblages along the entire length of the estuary to establish whether there were any relationships between a range of abiotic and biotic parameters and the spatial variation in fish assemblages.

\section{Headwater fish study}

\section{Sampling protocol}

Sampling was conducted monthly from January to December 1999. The littoral zone was sampled over high tide at Sites 31 to 40 (Fig. 1) using a $5 \times 1.5 \mathrm{~m}$ anchovy seine net (10 mm stretch mesh). Each seine net haul swept an estimated $35 \mathrm{~m}^{2}$ area. All fish were fixed in $10 \%$ formalin on site and transported back to the laboratory for analysis.

\section{Data analysis}

In the laboratory all fish were counted, identified to species level where possible and measured to the nearest $\mathrm{mm}$ standard length (SL). Mullet $<20 \mathrm{~mm}$ SL were recorded as Mugilidae but $M$. capensis $<20 \mathrm{~mm}$ SL were subsequently extracted from this pooled sample for the construction of a length-frequency histogram for this species. Average CPUE (average number of fish captured per haul), percentage composition and frequency of occurrence, was calculated for each species. The estuary-association categories assigned to each species conform to those of Whitfield (1998), i.e. Category I comprise those species which breed in South African estuaries, Category II are those marine species that breed at sea and use estuaries as nursery areas, Category III are marine 'stragglers' which occur in estuaries in small numbers, Category IV are freshwater species, and Category $\mathrm{V}$ comprises obligate and facultative catadromous taxa. The percentage that each category contributed to the total catch was calculated.

\section{Fish distribution study}

\section{Sampling protocol}

Samples were collected during January, May, July and October 1999. Within each season all 40 sites (Fig. 1) were seined over two consecutive days using the sampling protocol described above. In addition, the percentage vegetation cover was visually assessed and mid-water $(0.5 \mathrm{~m}$ depth) temperature, salinity, turbidity, percentage oxygen concentration and $\mathrm{pH}$ were measured at each site.

\section{Data analysis}

The mean ichthyofaunal density data collected during each season ( $n=40$ samples/sites) were fourth-root transformed to weight the contributions of common and rare species. An association matrix was produced using the Bray-Curtis similarity measure, from which classification and ordination procedures were conducted. The similarity matrix was classified using hierarchical agglomerative clustering with group average linking (Clarke and Warwick, 1994). Based on the results of the cluster analysis, the estuary was divided into six regions. Average CPUE and percentage composition were then calculated for each species in each region. Species richness (Margalef index) was also calculated for the fish assemblages found in each of the six groupings (Washington, 1984).

The extent of the relationships between the fish assemblages and selected environmental variables (percentage vegetation cover, water temperature, salinity, turbidity and dissolved oxygen concentration) were examined using the BIOENV sub-routine of PRIMER (Clarke and Warwick, 1994).

\section{Results and discussion}

\section{Headwater fish study}

\section{Composition and abundance}

A total of 9362 fishes were captured in the seine net, representing 19 species and 13 families. The dominant species were Glossogobius callidus, Gilchristella aestuaria, Myxus capensis and Rhabdosargus holubi, which together comprised $78.6 \%$ of the headwaters' ichthyofauna (Table 1). The abundance of the catadromous M. capensis in this region is almost certainly a reflection of the inability of this species to access the freshwater habitats above the estuary due to river flow being reduced to a trickle during the study period.

The number of species sampled in the Kariega headwaters (9 species) was lower than that recorded in the headwaters of the adjacentKowie Estuary (11 species) (Bok, 1983) and the Kieskamma Estuary (15 species) (Rayner, 1993). In contrast to the freshwater 'deprived' Kariega headwaters, 32 species have been recorded in the headwaters of the freshwater 'rich' Great Fish Estuary, with the 
TABLE 1

Species composition, CPUE, estuary-association categories and frequency of occurrence of fishes caught in the Kariega Estuary headwaters

\begin{tabular}{|c|c|c|c|c|c|c|}
\hline Species & $\begin{array}{c}\text { Association } \\
\text { category }\end{array}$ & Total (n) & $\begin{array}{l}\text { Average } \\
\text { CPUE }\end{array}$ & SD & $\begin{array}{l}\text { Percentage } \\
\text { composition }\end{array}$ & $\begin{array}{c}\text { Frequency of } \\
\text { occurrence }\end{array}$ \\
\hline Glossogobius callidus & I & 2314 & 19.3 & 26.5 & 24.7 & 100 \\
\hline Gilchristella aestuaria & $\mathrm{I}$ & 2226 & 18.6 & 40.1 & 23.7 & 100 \\
\hline Myxus capensis & V & 1518 & 12.7 & 26.0 & 16.2 & 100 \\
\hline Rhabdosargus holubi & II & 1313 & 10.9 & 15.7 & 14.0 & 100 \\
\hline Mugil cephalus & II & 784 & 6.5 & 41.6 & 8.4 & 83.3 \\
\hline Monodactylus falciformis & II & 644 & 5.4 & 14.1 & 6.8 & 83.3 \\
\hline Atherina breviceps & I & 405 & 3.4 & 16.7 & 4.3 & 75.0 \\
\hline Mugilidae $(<20 \mathrm{~mm})$ & - & 78 & 0.7 & 2.7 & 0.8 & 33.3 \\
\hline Oreochromis mossambicus & IV & 34 & 0.3 & 1.1 & 0.4 & 33.3 \\
\hline Gerres acinaces & II & 18 & 0.2 & 1.0 & 0.2 & 33.3 \\
\hline Barbus pallidus & IV & 10 & 0.1 & 0.4 & 0.1 & 50.0 \\
\hline Caffrogobius gilchristi & I & 6 & 0.1 & 0.3 & $<0.1$ & 33.3 \\
\hline Liza tricuspidens & II & 4 & $<0.1$ & 0.3 & $<0.1$ & 8.3 \\
\hline Solea bleekeri & II & 2 & $<0.1$ & 0.1 & $<0.1$ & 16.6 \\
\hline Syngnathus acus & $\mathrm{I}$ & 1 & $<0.1$ & 0.1 & $<0.1$ & 8.3 \\
\hline Caffrogobius nudiceps & I & 1 & $<0.1$ & 0.1 & $<0.1$ & 8.3 \\
\hline Pomadasys commersonnii & II & 1 & $<0.1$ & 0.1 & $<0.1$ & 8.3 \\
\hline Ambassis gymnocephalus & $\mathrm{I}$ & 1 & $<0.1$ & 0.1 & $<0.1$ & 8.3 \\
\hline Psammogobius knysnaensis & I & 1 & $<0.1$ & 0.1 & $<0.1$ & 8.3 \\
\hline Lithognathus lithognathus & II & 1 & $<0.1$ & 0.1 & $<0.1$ & 8.3 \\
\hline Total & & 9362 & & & & \\
\hline
\end{tabular}

R. holubi

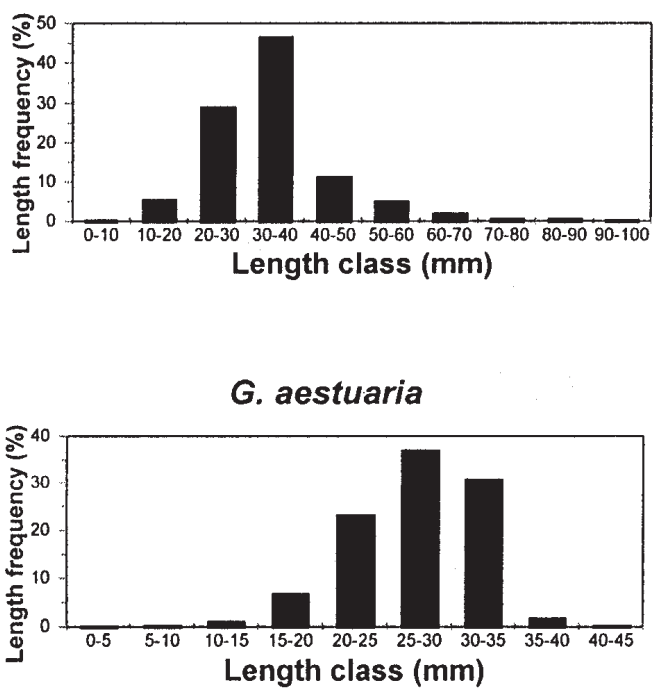

M. capensis

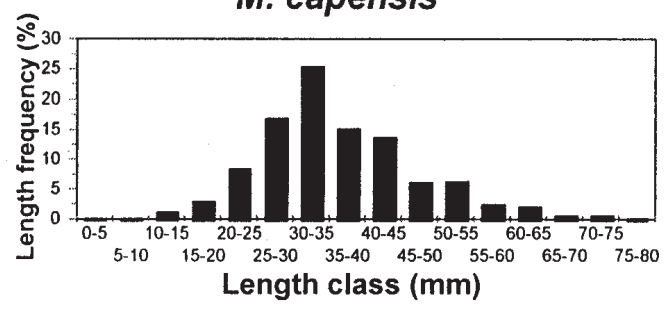

G. callidus

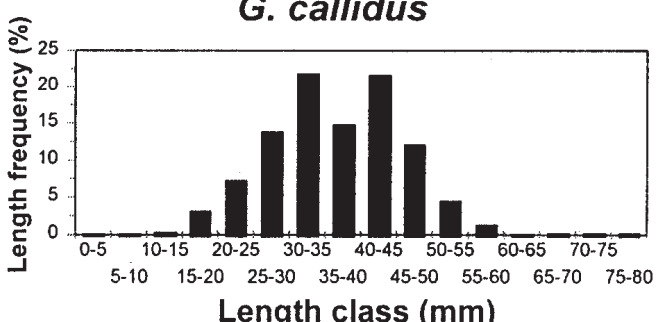

juveniles of a number of recreational angling species (e.g. Pomadasys commersonnii) being abundant in this reach (Ter Morshuizen et al., 1996). In the Kariega Estuary headwaters, juveniles of important angling species (e.g. Argyrosomus japonicus, Lithognathus lithognathus and P. commersonnii) were either scarce or absent (Table 1).

\section{Life history analysis}

Numerically the seine net ichthyofauna was dominated by estuarine species (Category I, 53\%), with marine species (Category II, 30\%) and catadromous species (Category V, 16\%) also making major contributions (Table 1). No marine stragglers (Category III) and very few freshwater fish (Category IV, $0.5 \%$ ) were sampled. The major marine species $R$. holubi and $M$. capensis were dominated by young of the year, while the primary estuarine species $G$. aestuaria and G. callidus were represented by both juveniles and adults (Fig. 2). The vast majority of fishes captured in the littoral zone were juveniles (Fig. 2) which conforms to the nursery function of estuarine margins (Whitfield, 1998), with the headwaters of these systems being particularly important to certain species (Rogers et al., 1984). 


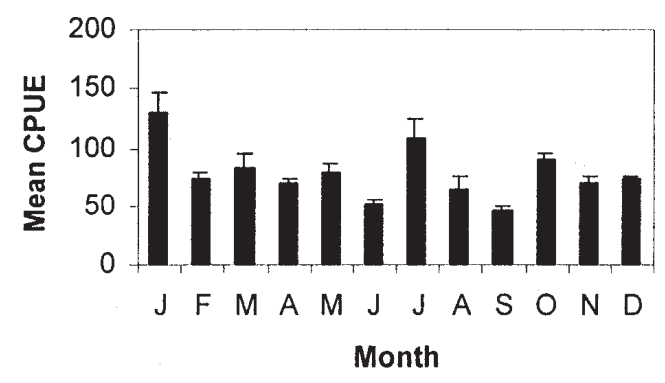

Figure 3

Mean CPUE (+1 S.E.) of the fishes sampled in the headwaters of the Kariega Estuary from January to December 1999
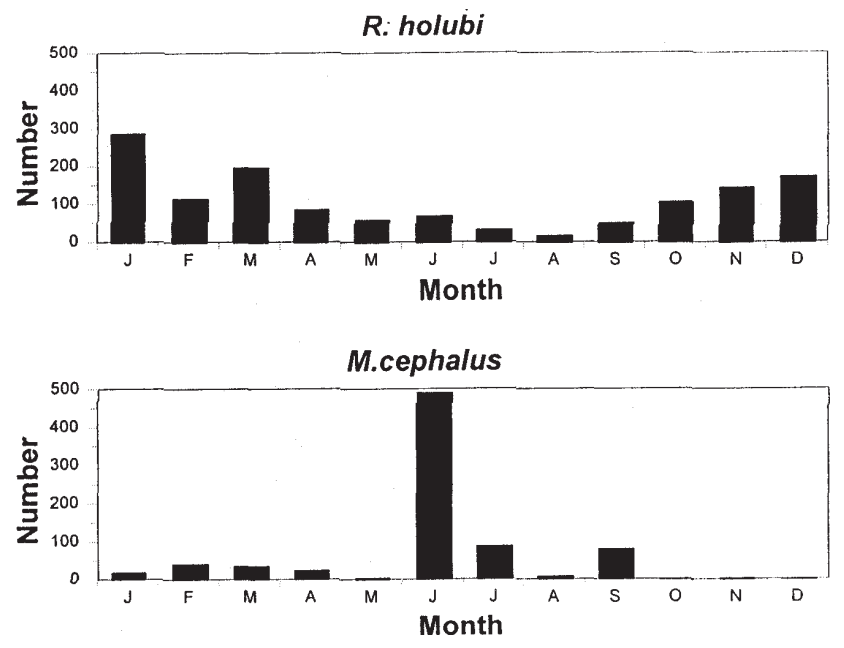

Figure 4

Monthly abundance values of $\mathrm{R}$. holubi and $\mathrm{M}$. cephalus caught in the headwaters of the Kariega Estuary from January to December 1999

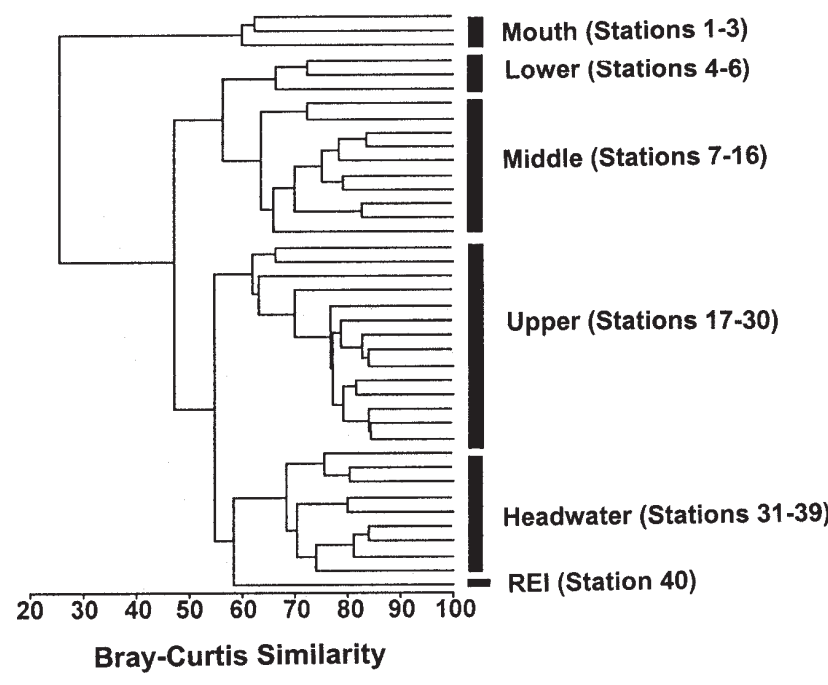

Figure 5

Dendrogram showing classification of the fish catches from 40 seining sites in the Kariega Estuary

\section{Seasonality}

Overall fish abundance did not show any clear trends (Fig. 3) but certain of the dominant species did display some seasonality. Rhabdosargus holubi exhibited a marked decrease in abundance during the winter months while newly recruited Mugil cephalus juveniles were most common in winter (Fig. 4). In contrast, studies in other habitats within the Kariega Estuary (e.g. Zostera capensis beds in the lower and middle reaches) exhibited clear peaks in overall abundance of fish during the spring and summer months (Paterson and Whitfield, 2000).

\section{Fish distribution study}

\section{Biotic and abiotic environment}

The average salinity in the Kariega Estuary was fairly constant (34 to $35 \%$ ) for the first 30 sites after which it dropped gradually to 23 $\%$ at Site 39 . The only site that recorded salinities $<5 \%$ oligohaline conditions) was Site 40 that had an average salinity of $3 \%$. Turbidities were low, ranging from 5 to 21 NTU. There were no clear turbidity trends, with the lowest values generally found in the mouth and headwater regions. The $\mathrm{pH}$ decreased slightly from Site 1 ( $\mathrm{pH} 8$ ) to site 39 ( $\mathrm{pH} 7.6$ ) but then increased to a $\mathrm{pH}$ of 8.2 at Site 40. The average water temperature increased up the length of the system from $17.2^{\circ} \mathrm{C}$ at Site 1 to $22.7^{\circ} \mathrm{C}$ at Site 39 and then declined to $20.2^{\circ} \mathrm{C}$ at Site 40 . All sites were well oxygenated, with a minimum dissolved oxygen value of $90 \%$ saturation.

No vegetation was recorded in the mouth region (Sites 1 and 2) or the headwaters (Sites 32 to 39). Zostera capensis was recorded from Sites 3 to 31 and the trend exhibited was one of decreasing plant cover, ranging from $>90 \%$ in the lower stations to $<50 \%$ in the upper stations. Site 40 had a $50 \%$ covering of Potamogeton pectinatus. While $Z$. capensis is common in the lower reaches of permanently open estuaries in the Eastern Cape, the low turbidity and marine dominance of the system has resulted in eelgrass beds extending into the upper reaches of the Kariega Estuary. This increased range of $Z$. capensis is characteristic of Eastern Cape estuaries that have had long-term reductions in freshwater inputs (Adams and Talbot, 1992).

\section{Composition and abundance}

In total 14011 fish, comprising 26 species, were sampled. The dendrogram constructed using fourth-root transformed abundance data clearly demonstrates that there are distinct ichthyofaunal assemblages along the length of the estuary (Fig. 5). At the $25 \%$ similarity level Sites 1 to 3 are separated from the remaining sites, indicating that the mouth region of the estuary has a very different ichthyofaunal community. At the $60 \%$ similarity level there are six clear groupings, namely the mouth (Sites 1 to 3), lower (Sites 4 to 6), middle (Sites 5 to 16), upper (Sites 17 to 30 ), headwaters (Sites 31 to 39 ) and the REI region (Site 40).

The ichthyofaunal assemblages in the different reaches (defined at the $60 \%$ similarity level) were distinct in that they were dominated by different species (Table 2). The mouth region was dominated by Liza dumerilii (58\%) while the lower reaches were dominated by R. holubi (45\%) and Clinus superciliosus (26\%). Similarly the middle reaches were dominated by $R$. holubi (39\%) but G. callidus $(19 \%)$ was also abundant. The upper reaches were dominated by $G$. callidus $(60 \%)$ whereas the headwaters had a number of important species, G. aestuaria (27\%), G. callidus (23\%) and M. cephalus (16\%). The REI region was dominated by M. capensis (36\%), M. falciformis (32\%) and G. callidus (26\%).

Very few recreationally important marine species (e.g. $P$. commersonnii and A. japonicus), which were common in the 


\begin{tabular}{|c|c|c|c|c|c|c|c|c|c|c|c|c|}
\hline \multicolumn{13}{|c|}{$\begin{array}{c}\text { TABLE } 2 \\
\text { Seine net catch per unit effort and percentage composition of fishes sampled in the Kariega Estuary } \\
\text { during this study }\end{array}$} \\
\hline \multirow[t]{2}{*}{ Species } & \multicolumn{2}{|c|}{$\begin{array}{c}\text { Mouth } \\
\text { (Sites } 1 \text { to } 3 \text { ) }\end{array}$} & \multicolumn{2}{|c|}{$\begin{array}{c}\text { Lower } \\
\text { (Sites } 4 \text { to } 6 \text { ) }\end{array}$} & \multicolumn{2}{|c|}{$\begin{array}{c}\text { Middle } \\
\text { (Sites } 7 \text { to 16) }\end{array}$} & \multicolumn{2}{|c|}{$\begin{array}{c}\text { Upper } \\
\text { (Sites } 17 \text { to } 30 \text { ) }\end{array}$} & \multicolumn{2}{|c|}{$\begin{array}{c}\text { Headwater } \\
\text { (Sites } 31 \text { to } 39 \text { ) }\end{array}$} & \multicolumn{2}{|c|}{$\begin{array}{c}\text { REI } \\
\text { (Site 40) }\end{array}$} \\
\hline & CPUE & $\%$ & CPUE & $\%$ & CPUE & $\%$ & CPUE & $\%$ & CPUE & $\%$ & CPUE & $\%$ \\
\hline Liza dumerilii & 35.8 & 57.7 & - & - & 0.2 & 0.3 & 1.0 & 1.0 & - & - & - & - \\
\hline Mugil cephalus & 8.8 & 13.9 & 1.6 & 1.9 & 6.2 & 9.7 & 0.4 & 0.4 & 16.2 & 16.9 & 3.7 & 3.1 \\
\hline Gilchristella aestuaria & 5.5 & 8.8 & 9.3 & 10.9 & 3.1 & 4.9 & 5.7 & 5.6 & 25.9 & 26.8 & 2.5 & 2.0 \\
\hline Atherina breviceps & 4.0 & 6.6 & 5.3 & 6.2 & 9.0 & 14 & 16.0 & 15.8 & 2.0 & 2.0 & - & - \\
\hline Psammogobius knysnaensis & 3.8 & 6.1 & - & - & - & - & - & - & - & - & - & - \\
\hline Diplodus sargus & 1.8 & 2.8 & 3.3 & 3.9 & 0.2 & 0.4 & - & - & - & - & - & - \\
\hline Rhabdosargus globiceps & 1.0 & 1.6 & - & - & - & - & - & - & - & - & - & - \\
\hline Sarpa salpa & 0.7 & 1.2 & - & - & - & - & - & - & - & - & - & - \\
\hline Pomadasys olivaceum & 0.4 & 0.6 & - & - & $<0.1$ & $<0.1$ & - & - & - & - & - & - \\
\hline Mugilidae (<20 mm) & 0.3 & 0.5 & - & - & 0.3 & 0.5 & 0.4 & 0.4 & 0.4 & 0.4 & 1.5 & 1.3 \\
\hline Rhabdosargus holubi & - & - & 38.3 & 44.9 & 25.2 & 39.2 & 15.8 & 15.6 & 14.0 & 14.5 & - & - \\
\hline Clinus superciliosus & - & - & 21.7 & 25.6 & 3.0 & 4.7 & - & - & - & - & - & - \\
\hline Caffrogobius nudiceps & - & - & 2.9 & 3.4 & 0.7 & 1.1 & $<0.1$ & $<0.1$ & - & - & - & - \\
\hline Diplodus cervinus & - & - & 1.0 & 1.3 & $<0.1$ & $<0.1$ & - & - & - & - & - & - \\
\hline Syngnathus acus & - & - & 0.8 & 1.0 & 0.3 & 0.5 & - & - & - & - & - & - \\
\hline Caffrogobius natalensis & - & - & 0.8 & 1.0 & 1.3 & 2.1 & - & - & - & - & - & - \\
\hline Glossogobius callidus & - & - & - & - & 12.4 & 19.2 & 61.1 & 60.4 & 22.0 & 22.8 & 26.7 & 22.2 \\
\hline Caffrogobius gilchristi & - & - & - & - & 1.3 & 2.0 & - & - & - & - & - & - \\
\hline Myxus capensis & - & - & - & - & 0.4 & 0.6 & 0.3 & 0.3 & 13.8 & 14.2 & 44.2 & 36.8 \\
\hline Solea bleekeri & - & - & - & - & $<0.1$ & $<0.1$ & - & - & - & - & - & - \\
\hline Siganus sutor & - & - & - & - & $<0.1$ & $<0.1$ & - & - & - & - & - & - \\
\hline Monodactylus faliciformis & - & - & - & - & $<0.1$ & $<0.1$ & - & - & 1.7 & 1.7 & 38.7 & 32.2 \\
\hline Arothron immaculatis & - & - & - & - & $<0.1$ & $<0.1$ & - & - & - & - & - & - \\
\hline Pomadasys commersonnii & - & - & - & - & - & - & $<0.1$ & $<0.1$ & - & - & - & - \\
\hline Heteromycteris capensis & - & - & - & - & - & - & $<0.1$ & $<0.1$ & - & - & - & - \\
\hline Oreochromis mossambicus & - & - & - & - & - & - & - & - & 0.3 & 0.4 & 1.7 & 1.5 \\
\hline Total & 62 & 100 & 85 & 100 & 64 & 100 & 101 & 100 & 96 & 100 & 119 & 100 \\
\hline
\end{tabular}

Great Fish Estuary (Ter Morshuizen et al., 1996), were found in the Kariega Estuary. The concentration of the juveniles of these species in the REI region of freshwater-rich estuaries (e.g. Great Fish), in conjunction with their scarcity or absence along the entire length of a freshwater-deprived estuaries (e.g. Kariega), has major implications for fish stocks which utilise the REI region of estuaries as nursery areas. While further research is needed, it may be postulated that if freshwater is abstracted from a system and it results in a reduction of the REI region, there will be a concomitant reduction in suitable nursery areas available to species such as P. commersonnii and A. japonicus.

The extent of estuarine association of the fish assemblages in the various reaches exhibited some clear trends (Fig. 6). The estuarine species (Category I) were more prevalent in the upper reaches, while the percentage of marine species (Category II) decreased from the mouth towards the headwaters and then increased again in the REI. Very few marine stragglers (Category III) and freshwater fish (Category IV) were captured, with the marine stragglers being restricted to the mouth and the freshwater fish to the REI region. Catadromous taxa (Category V) were found predominantly in the headwaters and REI region. The compression of the facultative catadromous Myxus capensis into these upper regions is probably a reflection of the lack of available riverine habit above the estuary during this study period, thus forcing newly recruited $M$. capensis to abandon their normal upstream migration pattern and remain within the estuarine environment.

The average number of species captured in the six reaches ranged between 6.6 and 12.3, with the highest richness (R) being found in the mouth, lower and middle reaches (Table 3 ). This trend of decreasing species richness and diversity in an upstream direction is similar to that found in a previous study of the Kariega Estuary eelgrass beds (Ter Morshuizen and Whitfield, 1994) as well as research in the Elbe Estuary, Germany (Thiel et al., 1995). In contrast, the freshwater 'rich' Great Fish system had a high ichthyofaunal diversity in the river immediately above the estuary, with lower diversities recorded towards the mouth (Ter Morshuizen et al., 1996).

Many of the marine stragglers (e.g. Diplodus cervinus hottentotus and Pomadasys olivaceum) that are found in the mouth and lower reaches of the Kariega Estuary are restricted to that region even though full seawater conditions extend for another 10 $\mathrm{km}$ upstream. The restricted distribution of these marine stragglers and absence of other common marine inshore species (e.g. Pachymetopon grande, Oplegnathus conwayi and Chirodactylus brachydactylus) from the system indicate that, while the Kariega often has full seawater for over $80 \%$ of its length, it is not an 'arm' of the sea but rather functions as a freshwater-deprived estuary.

The bio-environmental analysis, which correlates the results of 
the ichthyofauna classification (Fig. 5) to a range of abiotic and biotic variables, indicated that the best correlation for individual variables was temperature $(\mathrm{r}=0.57)$ and percentage vegetation cover $(r=0.35)$. Salinity, oxygen concentration and turbidity were
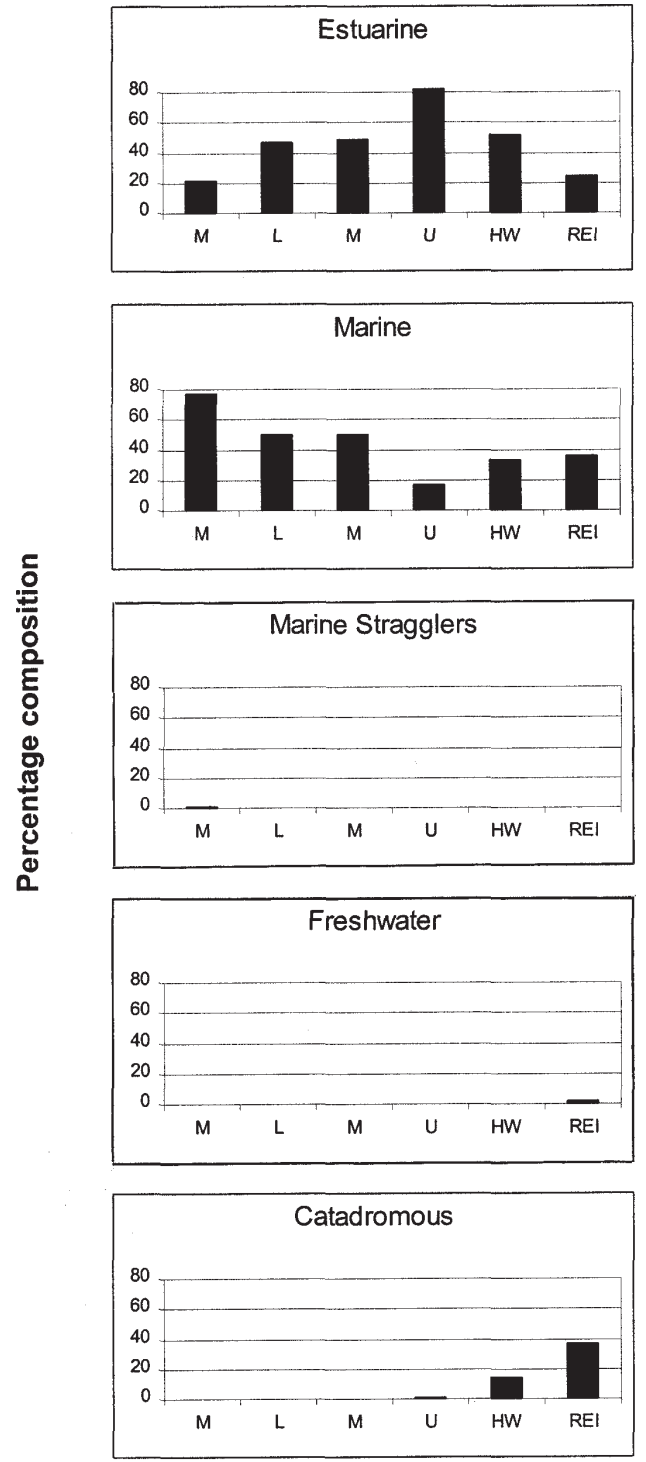

Estuary region

Figure 6

Percentage composition of the different fish estuarine-association categories in the Kariega Estuary ( $M=$ Mouth, $L=$ Lower reaches, Mid $=$ Middle reaches, $U=$ Upper reaches, $H W=$ Headwaters, $R E I=$ River-estuary interface zone) all poorly correlated to the ichthyofauna groupings in the Kariega Estuary. In contrast, salinity and turbidity were found to be the best individual correlates with the fish assemblages in the freshwater 'rich' Great Fish River Estuary (Ter Morshuizen et al., 1996). Turbidity is known to attract certain fish species (Cyrus and Blaber, 1987a; 1987b) but the lack of freshwater input into the Kariega Estuary has resulted in low turbidities $(<20$ NTU) throughout the system. Low oxygen concentrations have been shown to influence fish distribution in some KwaZulu-Natal estuaries (Begg, 1984; Blaber et al., 1984), but the oxygen saturation in the Kariega Estuary was consistently high ( $>90 \%$ saturation). The consistently clear and well-oxygenated waters in the littoral reaches of the Kariega Estuary excludes these factors as structuring forces influencing the recorded fish distribution.

The best combination of variables accounting for changes in fish assemblage structure was temperature, salinity and percentage vegetation cover $(r=0.62)$. Salinity is generally regarded as one of the major abiotic forces involved in structuring fish communities in estuaries, e.g. fish assemblages in the Elbe Estuary were found to be predominantly influenced by salinity and temperature with day time and tidal cycle also being important (Thiel et al., 1995). Similarly, salinity and temperature were the dominant environmental influences on the fish assemblage of the Humber Estuary (Marshall and Elliott, 1998). In contrast, salinity in the Kariega Estuary cannot be regarded as a dominant structuring force, as there were distinct fish communities associated with the mouth, lower and middle reaches where there was no longitudinal salinity gradient. An earlier study on the fishes associated with $Z$. capensis beds in the Kariega Estuary (Ter Morshuizen and Whitfield, 1994), established that distributional patterns of most fish species associated with Z. capensis were similar to other estuaries in the Eastern Cape with normal axial salinity gradients, indicating that salinity was not an important ichthyofaunal structuring force in this system.

The bio-environmental analysis also indicated that percentage vegetation cover may be an important environmental factor affecting fish distribution. This result is supported by other studies that have shown that eelgrass influences fish abundance and community composition in estuaries (Branch and Grindley, 1979; Beckley, 1983). Submerged aquatic vegetation provides shade, reduced water currents and increased surface area, while the rhizome mat may provide further habitat complexity (Bell and Pollard, 1989; Orth, 1992). These attributes, together with high primary productivity, are presumed to provide an abundant and varied supply of food, as well as protection from predators.

While a combination of temperature, percentage vegetation cover and salinity best correlates with the various fish assemblages, this correlation is not exceptionally high, indicating that other untested factors (e.g. tidal phase) may well be important. Marshall and Elliott's (1998) study on the Humber Estuary also found that the range of variables measured only partly explained the variance displayed by the fish assemblages, and they concluded that other

\begin{tabular}{|c|c|c|c|c|c|c|}
\hline \multicolumn{7}{|c|}{$\begin{array}{c}\text { TABLE } 3 \\
\text { Species number }(\mathrm{n}) \text { and richness (R) of the different fish assemblages identified } \\
\text { at the } 60 \% \text { similarity level (cf. Fig. } 5 \text { ) }\end{array}$} \\
\hline & $\begin{array}{c}\text { Mouth } \\
\text { (Sites } 1 \text { to } 3 \text { ) }\end{array}$ & $\begin{array}{c}\text { Lower } \\
\text { (Sites } 4 \text { to 6) }\end{array}$ & $\begin{array}{c}\text { Middle } \\
\text { (Sites } 7 \text { to } 16)\end{array}$ & $\begin{array}{c}\text { Upper } \\
\text { (Sites } 17 \text { to } 30)\end{array}$ & $\begin{array}{l}\text { Headwater } \\
\text { (Sites } 31 \text { to } 39 \text { ) }\end{array}$ & $\begin{array}{c}\text { REI } \\
\text { (Site 40) }\end{array}$ \\
\hline Average species number (n) & 9.0 & 12.3 & 11.8 & 6.6 & 7.4 & 8.0 \\
\hline Species richness $(\mathrm{R})$ & 2.2 & 2.6 & 2.6 & 1.3 & 1.4 & 1.4 \\
\hline
\end{tabular}


factors such as predator prey interactions, as well as prey distribution may affect distribution patterns. From the above it becomes apparent that although salinity has been shown to be an important structuring force influencing fish assemblages in many estuaries, it is not the primary factor governing the distribution of fish in a freshwaterdeprived and marine-dominated system such as the Kariega.

\section{Acknowledgements}

We thank Professor Sarah Radloff of the Department of Statistical Sciences at Rhodes University for statistical advice, and the Department of Water Affairs and Forestry for use of unpublished river flow and water conductivity data. This study was funded by the Water Research Commission and the National Research Foundation.

\section{References}

ADAMS JB and TALBOT MM (1992) The influence of river impoundment on the estuarine seagrass Zostera capensis Setchell. Bot. Mar. 35 69-75.

ALLANSON BR and READ GHL (1995) Further comment on the response of Eastern Cape Province estuaries to variable freshwater inflows. South. Afr. J. Aquat. Sci. 21 (1/2) 56-70.

BATE GC, WHITFIELD AK, ADAMS JB, HUIZINGA P and WOOLDRIDGE TH (2002) The importance of the river-estuary interface zone in estuaries. Water SA 28 (3) 271-279.

BECKLEY LE (1983) The ichthyofauna associated with Zostera capensis Setchell in the Swartkops estuary, South Africa. S. Afr. J. Zool. 18 15-24.

BEGG GW (1984) The Estuaries of Natal. Part 2. Natal Town and Regional Planning Report No. 55.631 pp.

BELL JD and POLLARD DA (1989) Ecology of fish assemblages and fisheries associated with seagrasses. In: AWD Larkum, AJ McComb and SA Shepard (eds.) Biology of Seagrasses. Elsevier, Amsterdam. 565-609.

BLABER SJM, HAY DG, CYRUS DP and MARTIN TJ (1984) The ecology of two degraded estuaries on the north coast of Natal, South Africa. S. Afr. J. Zool. 19 224-240.

BOK AH (1983) The Demography, Breeding Biology and Management of Two Mullet Species (Pisces: Mugilidae) in the Eastern Cape, South Africa. Ph.D. Thesis, Rhodes Univ., Grahamstown.

BRANCH GM and GRINDLEY JR (1979) Ecology of southern African estuaries. Part XI. Mngazana: A mangrove estuary in the Transkei. S. Afr. J. Zool. 14 149-170.

CLARKE KR and WARWICK RM (1994) Change in marine communities: An approach to statistical analysis and interpretation. Natural Environment Research Council, Plymouth. 144 pp.

CYRUS DP and BLABER SJM (1987a) The influence of turbidity on juvenile marine fish in the estuaries of Natal, South Africa. Cont. Shelf Res. 7 1411-1416.

CYRUS DP and BLABER SJM (1987b) The influence of turbidity on juvenile fishes in estuaries. Part 2. Laboratory studies, comparisons with field data and conclusions. J. Exp. Biol. Ecol. 109 71-91.
GRANGE N (1992) The Influence of Contrasting Freshwater Inflows on the Feeding Ecology and Food Resources of Zooplankton in Two Eastern Cape Estuaries, South Africa. Ph.D. Thesis, Rhodes Univ., Grahamstown. 230 pp.

GRANGE N and ALLANSON BR (1995) The influence of freshwater inflow on the nature, amount and distribution of seston in estuaries in the eastern Cape, South Africa. Est. Coast. Shelf Sci. 40 403-420.

GRANGE N, WHITFIELD AK, DE VILLIERS CJ and ALLANSON BR (2000) The response of two South African estuaries to altered river flow regimes. Aquat. Cons. Mar. Freshw. Ecosyst. 10 155-177.

HODGSON AN (1987) Distribution and abundance of the macrobenthic fauna of the Kariega Estuary. S. Afr. J. Zool. 22 153-162.

MARSHALL S and ELLIOTT M (1998) Environmental influences on the fish assemblage of the Humber Estuary, UK. Est. Coast. Shelf Sci. 46 175-184.

MORIN B, HUDON C and WHORISKEY FG (1992) Environmental influences on seasonal distribution of coastal and estuarine fish assemblages at Wemindji, eastern James Bay. Environ. Biol. Fish. 35 219-229.

ORTH RJ (1992) A perspective on plant-animal interactions in seagrasses: physical and biological determinants influencing plant and animal abundance. In DM John, SJ Hawkins and JH Price (eds.) Plant-animal Interactions in the Marine Benthos. System. Assoc. (Special Vol.) 46 147-164.

PATERSON AW and WHITFIELD AK (2000) The ichthyofauna associated with an intertidal creek and adjacent eelgrass beds in the Kariega Estuary, South Africa. Environ. Biol. Fish. 58 145-156.

RAYNER JL (1993) A Study on the Ichthyofauna of the Kieskamma River Ebb and Flow Region with Emphasis on Diversity and Seasonality of their Migrations. B.Sc. Project, Rhodes Univ., Grahamstown.

REDDERING JSV and RUST IC (1990) Historical changes and sedimentary characteristics of southern African estuaries. S. Afr. J. Sci. 86 425-428.

ROGERS SG, TARGETT TE and VAN SANT SB (1984) Fish-nursery use in Georgia salt-marsh estuaries: The influence of springtime freshwater conditions. Trans. Am. Fish. Soc. 113 595-606.

TER MORSHUIZEN LD and WHITFIELD AK (1994) The distribution of littoral fish associated with eelgrass Zostera capensis beds in the Kariega Estuary, a southern African system with a reversed salinity gradient. S. Afr. J. Mar. Sci. 14 95-105.

TER MORSHUIZEN LD, WHITFIELD AK and PATERSON AW (1996) Influence of freshwater flow regime on fish assemblages in the Great Fish River and estuary. South. Afr. J. Aquat. Sci. 22 52-61.

TER MORSHUIZEN LD, WHITFIELD AK and PATERSON AW (1997) Distribution patterns of fishes in an Eastern Cape estuary and river with particular emphasis on the ebb and flow region. Trans. Roy. Soc. S. Afr. 51 257-280.

THIEL R, SEPULVEDA A, KAFEMANN R and NELLEN W (1995) Environmental factors as forces structuring the fish community of the Elbe Estuary. J. Fish Biol. 46 47-69.

WASHINGTON HG (1984) Diversity, biotic and similarity indices. A review with special relevance to aquatic ecosystems. Water Res. 18 653-694.

WHITFIELD AK (1998) Biology and ecology of fishes in southern African estuaries. Ichthyol. Monogr. J.L.B. Smith Inst. Ichthyol. 2 1-223. 
